\title{
Organizing a Rainbow Coalition of Revolutionary Solidarity
}

Jeb Aram Middlebrook ${ }^{1}$

\begin{abstract}
This article considers the possibilities and limitations of multiracial alliances and antiracist organizing in and beyond the USA by analyzing the Rainbow Coalition of Revolutionary Solidarity in Chicago from 1969 to 1972. The article argues this coalition-involving the Black Panther Party, Young Lords, and Young Patriots, among other diverse organizations - demonstrated a powerful model of organizing across race for revolutionary social change, which structured self-determination in communities-of-color alongside white communities' responsibility for ending white supremacy.
\end{abstract}

Keywords Multiracial alliance $\cdot$ Antiracist organizing $\cdot$ Rainbow Coalition of Revolutionary Solidarity · Self-determination · Black Power · Autonomous-affiliate organizing

Jeb Aram Middlebrook

jeb@middlebrookllc.com

1 Founding Partner of Research \& Development, MiddlebrookLLC.com, Long Beach,

California, USA 


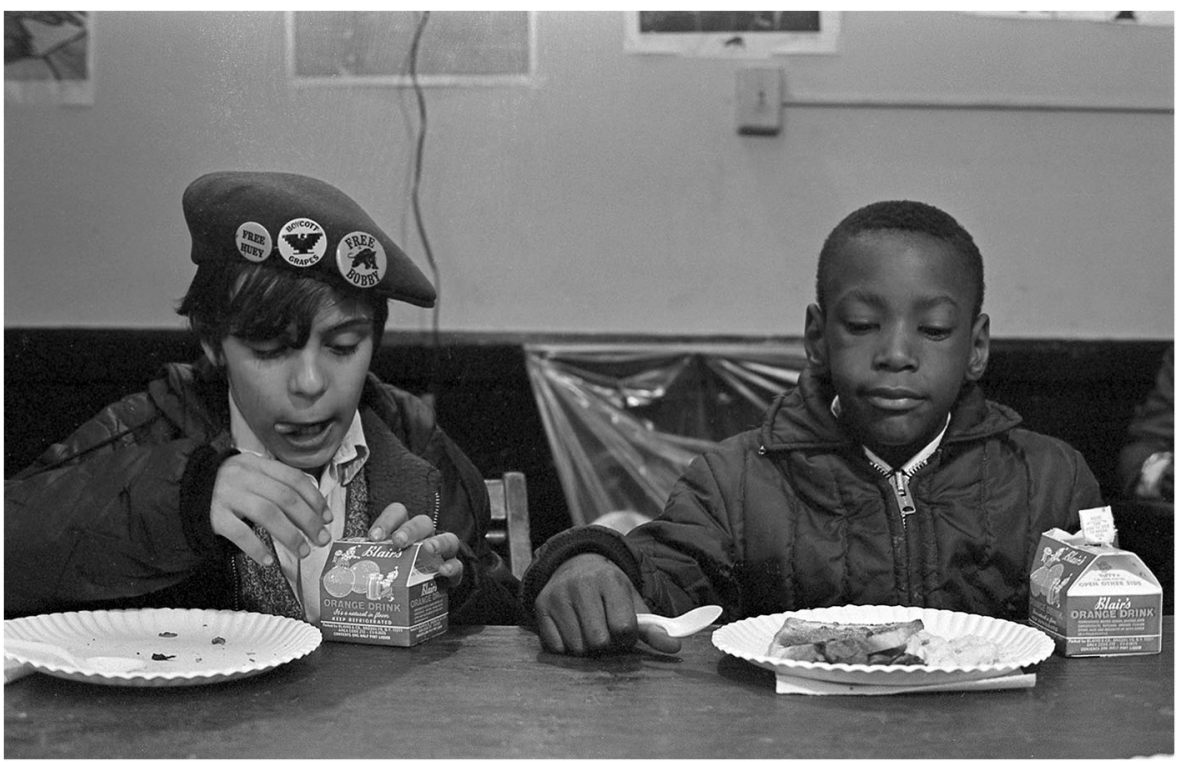

Black Panther Party Free Breakfast for Children Program" (1969) / Bev Grant / Getty Images / BevGrantPhotography.com

We got to face some facts. That the masses are poor, that the masses belong to what you call the lower class, and when I talk about the masses, I'm talking about the white masses, I'm talking about the black masses, and the brown masses, and the yellow masses, too....We're gonna fight racism with solidarity...capitalism with socialism.

-Fred Hampton, Deputy Chairman, Chicago chapter of the Black Panther Party, 1969 (Hampton 1969).

In 1968, two independent groups in Chicago, one on the West side and one on the South side, began unofficial chapters of the Black Panther Party. The two groups merged after the national headquarters granted the South side chapter an official charter (Civil Rights 2019). Not long after the founding of the Illinois State Chapter of the Black Panther Party, Fred Hampton's approach to organizing in Chicago centered black self-determination but also included attempts at a multiracial coalition with other organizations-of-color such as the Puerto Rican-led Young Lords, and white-led organizations such as the Young Patriots and Students for a Democratic Society. These various organizational partnerships were announced collectively by the BPP as the "Rainbow Coalition of Revolutionary Solidarity" (Rainbow Coalition, for short) in May of 1969 (Kaufman 1969), and both modeled and inspired class-conscious organizing across race against white supremacist capitalism. ${ }^{1}$

The Rainbow Coalition echoed the autonomous-affiliate organizing model of the Student Non-Violent Coordinating Committee (SNCC) and the Southern Student

\footnotetext{
${ }^{1}$ Although not the same coalition, the Rainbow Coalition inspired the Reverend Jesse Jackson to later adopt the name, "The National Rainbow Coalition," as part of his 1984 presidential campaign.
} 
Organizing Committee (SSOC), the latter which ended the same year the Rainbow Coalition began. The shared organizing model involved different racialized groups organizing separately in their respective communities but remaining in organizational alliance. It was an intentional political strategy to build self-determination in communities of color side-by-side with whites taking active responsibility for white racism and for ending the white supremacist system.

This article discusses the further development of the autonomous-affiliate organizing model in the late 1960s as it was reflected by black, brown, and white organizations in Chicago under the auspices of the Rainbow Coalition. This work examines the ways in which antiracist organizing transformed individual racial identities of organizational members as it sought to transform the white supremacist system. Particular to this history is the ideological shift within articulations of Black Power by the Black Panther Party toward "people power," which explicitly named and included non-black people in their vision for liberation. This essay analyzes the implications of SNCC's prior reframing of coalition politics for Rainbow Coalition organizers and analyzes the model of a multiracial vanguard in the alliance between the BPP, the Puerto Rican Young Lords, and the white Appalachian Young Patriots. Lastly, this work continues to examine the contradictions inherent in white antiracist organizing through a profile of the Young Patriots. Methodologically, the piece uses white organizers and organizers of color's documentation of themselves in literature and film as a lens to consider the connections between self-representation and community mobilization.

\section{The Roles of Whites}

The Black Panthers' organizing of poor and working-class black people fueled attempts to politicize and unite with black organizations such as the Blackstone Rangers; Puerto Rican organizations, such as the Young Lords; and white organizations, such as the Young Patriots. Many members of these organizations had emerged from Chicago's street gangs. The BPP believed that the lumpenproletariat - a group of people largely dismissed by Karl Marx as politically viable and labeled the "refuse, offal and wreck of all classes," including "vagabonds, discharged convicts, swindlers, tricksters, beggars" (Marx 1913, 83)—could be organized for revolution. Marx's perception was that such a group of people were not workers in the traditional sense, and therefore did not carry the potential of classconsciousness or class revolution. The BPP believed differently. Huey P. Newton, BPP Co-founder, argued in 1970 that "as the ruling circle continue to build their technocracy, more and more of the proletariat will become unemployable, become lumpen, until they have become the popular class, the revolutionary class" (Epps 1970). This understanding, as enacted in the Chicago chapter of the BPP under Fred Hampton's leadership, extended to a multiracial coalition of white people and people of color against the systems of white supremacy and capitalism.

In 1968, Newton offered an interview to the SNCC newspaper, The Movement, and in which he addressed the role of whites in relation to the BPP: 
MOVEMENT: The Black Panther Party has had considerable contact with white radicals since its earliest days. What do you see as the role of these white radicals?

HUEY: The white mother country radical is the off-spring of the children of the beast that has plundered the world exploiting all people, concentrating on the people of color. These are children of the beast that seek now to be redeemed because they realize that their former heroes who were slave masters and murderers, put forth ideas that were only facades to hide the treachery they inflicted upon the world. They are turning their backs on their fathers.

Newton recognized the tensions inherent in whites challenging white supremacy, and that the process was, in part, one of redemption against a history of white racism. He also understood the price paid by whites who chose a path of redemption-a choice that sometimes divided white families. Newton furthered:

The white mother country radical, resisting the system, becomes somewhat of an abstract thing because he's not oppressed as much as black people are. As matter of fact his oppression is somewhat abstract simply because he doesn't have to live in a reality of oppression. Black people in America and colored people throughout the world suffer not only from exploitation, but they suffer from racism. Black people here in America, in the black colony, are oppressed because we're black and we're exploited. The whites are rebels, many them from the middle class and as far as any overt oppression this is not case.

Here, Newton articulated a layered definition of the white supremacist system-one that recognized the distinct racial histories of black people and white people in the USA, but he also made room for a common vision across race where a collective rejection of the white supremacist system might be possible. In Newton's terms, oppression of whites under the white supremacist system was "abstract" and far from "overt." Nevertheless, he articulated that the system is responsible for the oppression of both whites and people of color, although to different degrees. It is these shared, yet differentiated, threads of exploitation and resistance across race that informed the BPP's theoretical and practical approach to working with radical whites and other people of color in what later became the Rainbow Coalition.

The Movement interview with Newton also reflected on past difficulties black organizations had in organizing with whites and addressed the question of why the BPP was successful in its efforts:

MOVEMENT: Other black groups seem to feel that from past experience it is impossible for them to work with whites and impossible for them to form alliances. What do you see as the reasons for this and do you think that the history of the Black Panther Party makes this less of a problem?

HUEY: There was somewhat of an unhealthy relationship in the past with the white liberals supporting black people who were trying to gain their freedom. I think a good example of this would be the relationship that SNCC had with its white liberals because they differ strictly from the white radicals. The relationship was the whites controlled SNCC for a very long time. From the very start of SNCC until here recently [1966] whites were the mind of SNCC. 
They controlled the program of SNCC with money and they controlled the ideology, or the stands SNCC would take. The blacks in SNCC were completely controlled program-wise; they couldn't do any more than these white liberals wanted them to do, which wasn't very much. So the white liberals were not working for self-determination for the black community.

The transition to Black Power and black leadership within SNCC in 1966 was a pivotal moment for both blacks and whites in the civil rights movement. The decision politically divided many, both within the same racial groups as well as across race. Supporters of integration and multiracial organizations were disheartened. Many whites understood this turn in SNCC and the corresponding organizational decision to remove whites from leadership as an anti-white, rather than pro-black, strategy. Many blacks similarly felt the move was divisive. Newton addressed these tensions explicitly in the Movement interview:

Whites were afraid when Stokely [Carmichael] came along with Black Power and said that black people have a mind of their own and that SNCC would be an all-black organization and that SNCC would seek self-determination for the black community. The white liberals withdrew their support leaving the organization financially bankrupt...The result was that the leadership of SNCC turned away from the white liberal, which was very good.

I don't think they distinguished between the white liberal and the white revolutionary, because the white revolutionary is white also and they are very much afraid to have any contact whatsoever with white people.... If the mother country radicals are sincere then this will definitely add to the attack that we [the BPP] are making on the power structure. The Black Panther Party's program is a program where we recognize that the revolution in the mother country will definitely aid us in our freedom and has everything to do with our struggle!

Here, Newton offered a distinction between the white liberal and white revolutionary. Whiteness for Newton was not monolithic. The level of support for black selfdetermination was the criterion for Newton in determining the value of white alliances with blacks, and white contributions to the movement. In Newton's perspective, the lack of distinction between white liberals and white revolutionaries hampered the ability for past civil rights organizations, such as SNCC, to effectively move organizational alliances with whites. Newton explained that the BPP's approach to working with whites was different than that of SNCC's:.

The Black Panther Party has NEVER been controlled by white people. The Black Panther Party has always been a black group.... We have never been controlled by whites and therefore we don't fear the white mother country radicals. Our alliance is one of the organized black groups with organized white groups. As soon as the organized white groups do not do the things that would benefit us in our struggle for liberation, that will be our departure point. So we don't suffer in the hangup of a skin color. We don't hate white people; we hate the oppressor. And if the oppressor happens to be white then we hate him. When he stops oppressing us then we no longer hate him. And right now in America you have the slave-master being a white group. We are pushing him out of office through 
revolution in this country. I think the responsibility of the white revolutionary will be to aid us in this.

As Newton saw it, the question of white involvement was clearer for a people-of-colorled organization. For the BPP, white radicals were either (a) working in support of selfdetermination for black people, or (b) not working in support of self-determination for black people. The expectation for white revolutionaries was clear. Within the BPP's approach to work across race, white revolutionaries could fulfill the movement's objective of challenging the white supremacist system in racially separate organizations, while at the same time being in alliance with the efforts of radical, people-ofcolor organizations such as the BPP.

The autonomous-affiliate organizing model is at play here, although not explicitly named as such. The effectiveness of the model, particularly in the case of the BPP and the Rainbow Coalition that developed in Chicago, was largely due to the BPP's focus on black leadership and black self-determination in their organization. This approach did not discount alliances with whites or other people of color groups; it simply prioritized the work and strategy of black people. Rather than requiring a multiracial organization, the BPP opted for a multiracial movement. Newton also articulated a key (and underappreciated element) of autonomous-affiliate organizing: that is, the importance of whites organizing themselves for revolutionary struggle against white supremacy:

MOVEMENT: Do you see the possibility of organizing a white Panther Party in opposition to the establishment possibly among poor and working whites?

HUEY: ...Black Power is people's power and as far as organizing white people we give white people the privilege of having a mind and we want them to get a body. They can organize themselves. We can tell them what they should do, what their responsibility is if they're going to claim to be white revolutionaries or white mother country radicals, and that is to arm themselves and support the colonies around the world in their just struggle against imperialism. But anything more than that they will have to do on their own.

Newton's view of whites organizing whites against imperialism and white supremacy, both in the USA and abroad, echoed organizational statements by SNCC in 1966. SNCC argued similarly for a new form of "coalition politics" where "black people organize blacks and white people organize whites" (New York Times1966, 10). From within a Black Power stance, neither the BPP nor SNCC were against working with whites. It was simply a question of under what kind of organizational arrangements would whites and people of color work together. Radical whites who opted to organize white people toward antiracist and anti-imperialist ends were explicitly included in these black-led organizations' understandings of multiracial alliances and were welcomed as allies.

\section{Embodying Resistance}

The embodiment of antiracism for white people is indirectly indexed in Newton's remark about white people "having a mind and we want them to get a body." Newton's 
comments could be read as encouragement for white people to produce large numbers of white antiracists through organizing - as in the definition of body as "a number of persons...regarded as a group" (The Movement 1968, 8-11), for example, body politic. Newton surmised that white antiracism could function in the same way that white supremacy did, both on the individual and institutional level. Here, Newton's thinking underscores an embodied whiteness that articulates antiracism, alongside (or perhaps in place of) white supremacy. He shared his understanding of the biological-psychological underpinnings of both white supremacy and liberation in relation to black and white communities in his Movement interview:

MOVEMENT: You indicate that there is a psychological process that has historically existed in white-black relations in the U.S. that must change in the course of revolutionary struggle. Would you like to comment on this?

HUEY: Yes. The historical relationship between black and white here in America has been the relationship between the slave and the master; the master being the mind and the slave the body. The slave would carry out the orders the mind demanded him to carry out...He stripped black people of their mind. In the process the slave-master stripped himself of a body... So the slave lost his mind and the slave-master his body...The white man cannot...unite with the body because the body is black. The body is symbolic of slavery and strength. It's a biological thing as he views it.

The mind/body split that Newton identified here was precipitated by the history of slavery in the USA. The underpinnings of this idea, however, stemmed largely from the ancient writings of Plato in The Republic, which provided a philosophical justification for the order of the state. Plato understood the relationship between the mind and body as follows:

How far can the mind control the body? ...Must we not at any rate admit that there is in human nature a higher and a lower principle, divided by no distinct line, which at times break asunder and take up arms against one another? Or again, they are reconciled and move together... And then the body becomes the good friend or ally, or servant or instrument of the mind... Reason and the desires, the intellect and the senses are brought into harmony and obedience so as to form a single human being (Plato 1908, 61).

For Plato, the reconciliation of the human intellect and senses was achieved through the subordination of the body to the (superior) mind. This philosophical view informed Plato's commitment to a city-state ruled by philosopher-kings but dependent on servant labor. This was folded into the development of the slave trade and the white supremacist system as it came to develop in the USA. As Newton observed, the mind and body took on distinct racial connotations but not first without a dissociation of mind and body for both slaves and masters. Plato's "harmony and obedience," considered in racial and institutional terms, relied on a subordination of non-white labor to white reason.

Within the historical development of the white supremacist system in the USA, labor became coded as black and of color through expropriated and exploited native, slave, and immigrant labor. Reason and intellect became coded as white and became institutionalized as the rule of law. The history of racial ideology in the USA emerged largely 
from this mind/body split (Frederickson 1987). Both whites and people of color grapple with this legacy, as the development of racial thinking prescribed racial roles for both groups. Slavery and racial oppression in the USA thus functioned and functions as a collective trauma felt by all of the nation's residents. Newton identified the struggles for both people of color and whites in reconstituting their psychic and biological selves which historically have been split by this mind/body dualism. He noted the ways in which the unique racial histories of both groups paralleled their unique processes of reconstitution:

HUEY: The slave is in a much better situation because his not being a full man has always been viewed psychologically. And it's always easier to make a psychological transition than a biological one. If he can only recapture his mind...then he will lose all fear and will be free to determine his destiny. This is what is happening at this time with the rebellion of the world's oppressed people against the controller. They are regaining their mind and they're saying that we have a mind of our own. They're saying that we want freedom to determine the destiny of our people, thereby uniting the mind with their bodies. They are taking their mind back from the omnipotent administrator, the controller, the exploiter.

The process for whites, who also require a reunification of the mind and body, involved a different but related political process, according to Newton,

MOVEMENT: Would you be willing to extend this formula in terms of white radicals; to say that one of their struggles today is to get back their bodies?

HUEY: Yes. I thought I made that clear. The white mother country radical by becoming an activist is attempting to regain his body. By being an activist and not the traditional theoretician who outlines the plan, as the Communist Party has been trying to do for every so long, the white mother country radical is regaining his body. The resistance by white radicals in Berkeley during the past three nights is a good indicated that the white radicals are on the way home. They have identified their enemies. The white radicals have integrated theory with practice. They realize the American system is the real enemy...

Newton's reflections on praxis, or the integration of theory and practice, in relation to antiracism revealed a psychological and physical recovery process required for whites and people of color under the white supremacist system. Although coming from different racial histories with different psychological experiences, Newton articulated that both white people and people of color suffer traumas under white supremacy. The process of reunification - uniting mind and body individually and collectively within and across racial groups - according to Newton, could be accomplished through practical involvement in on-the-ground movement work against racism and white supremacy.

This theory is supported by a history of political and personal transformation occurring among white and black organizers who challenged the white supremacist system, such as the multiracial organizing work done by SNCC and SSOC in Mississippi, and in the Rainbow Coalition organizations in Chicago. Antiracist organizing and multiracial alliance can thus be understood as processes that simultaneously transform 
the individual and the institution in terms of racial reconciliation, providing for healing on the personal, communal, and national level. The Black Panthers were particularly attuned to the question of how to organize these "structures of healing" within a political framework that supported self-determination in communities of color alongside white responsibility for white supremacy. I turn to one of these frameworks now to unpack how autonomous-affiliate organizing worked on the ground.

\section{Towards a Coalition of Revolutionary Solidarity}

Kathleen Cleaver, the first female leader on the national decision-making body of the Black Panther Party, discussed the organization's vision for collective, multiracial organizing for social change. She wrote of the organizing and alliance model that emerged from Chicago as the Rainbow Coalition. Cleaver wrote, "We organized the Rainbow Coalition, pulled together our allies, including not only the Puerto Rican Young Lords, the youth gang called Black P. Stone Rangers, the Chicano Brown Berets, and the Asian (Red Guards), but also the predominately white Peace and Freedom Party and the Appalachian Young Patriots Party. We posed not only a theoretical but a practical challenge to the way our world was organized. And we were men and women working together" (Cleaver and Katsiaficas 2001, 125).

The BPP distinguished between different kinds of power. "Power to the people," an oftquoted phrase from the sixties' movements, emerged from the organizing work of the BPP. "Black Power," also a common sixties' reference slogan emerged from the teachings of Malcolm X and early SNCC organizing and was formalized by the Black Panther Party. Lesser known but particularly relevant to the current study is the phraseology of "Black power...brown power... and white power," articulated by at least three of the leading members of the BPP: Elbert Howard, Eldridge Cleaver, and Fred Hampton. Kathleen Cleaver explained, "In a world of racist polarization, we sought solidarity. We called for Black power for Black people, Red power for Red People, Brown power for Brown people, Yellow Power for Yellow people, and, as Eldridge Cleaver used to say, White power for White people, because all they'd known was 'Pig power' (Cleaver 1968). Elbert "Big Man" Howard, co-founder of the Black Panther Party said in 1968, and again at the fortieth anniversary of the BPP in 2006, "Unity in the Community! Black Power to Black People! White Power to White People! Brown Power to Brown People! Yellow Power to Yellow People! Red Power to Red People!" (Howard 2006). Fred Hampton reiterated the call at an organizing meeting of the Illinois State Chapter of the BPP in Chicago in 1968 (Alk 2007a, 2007b).

Similar to the parsing of liberal and revolutionary whiteness by Newton, Eldridge Cleaver and Elbert Howard sought to distinguish the white supremacist system from white people. Some believed these ideas, articulated as white radicalism or white power, flirted dangerously with a white nationalism undercurrent that found allies not only in the liberal white Left but in the white Right. Earlier critiques of Marcus Garvey's brand of African nationalism, which lauded the racial separatist ideology of the Ku Klux Klan, also resurfaced in relation to the BPP's privileging of Black Power (Draper 1970). The BPP's was different than previous articulations of nationalism, however. Some members of the BPP believed in racial separatism, but the organization as a whole saw such separatism as a political means, and not necessarily as an end. 
The BPP moved increasingly toward internationalism, and as Newton later called it, Intercommunalism, which understood the relationship between the black community and the USA as imperialist —one that could be overturned through black selfdetermination and alliance with other racial communities, including Third World peoples and whites, who opposed the white supremacist system and empire. A speech presented by Eldridge Cleaver, then Minister of Information of the Black Panther Party, to the primarily white Peace and Freedom Foundation Convention in 1968, reflected this goal. His talk, "Revolution in the White Mother Country \& National Liberation in the Black Colony," analyzed the coalition between the BPP and the Peace and Freedom Party. Cleaver said this:

The Black Panther Party believes that the era in which we now struggle can be characterized as the Age of the Showdown - between Oppressed People Everywhere and the Racist Imperial Power Structure.... what we need is a revolution in the white mother country and national liberation for the black colony.... Ideally, we need a revolutionary organization that is able, guided by a revolutionary ideology and comprehending the necessity involved, to move in two directions at the same time. The coalition between our two fraternal parties is based upon Carmichael's dictum of specific coalitions for specific purposes.... On the basis of this dictum, we think that ultimately we can develop a specific coalition for the specific purpose of destroying capitalism, exploitation and racism.

According to Cleaver, the coalition between the BPP and the white Peace and Freedom Party to fight for the release of Huey Newton from jail was a strategic partnership that had "national implications." The notion of joining multiracial revolutionary politics with electoral politics - using grassroots organizing to elect BPP leadership into government positions in the Bay Area, $\mathrm{CA}$ - had the potential to politically transform individuals, communities, and institutions, according to Cleaver.

The strategy to use this campaign to simultaneously organize against racism in the white community, and to develop self-determination in the black community, satisfied Cleaver's call for a revolutionary approach that could "move in two directions at the same time." It was a strategic alliance across racially separate organizations, however, and not a single multiracial organization that was able to accomplish the tasks of white antiracism and black self-determination simultaneously. A multiracial coalition, based on similar ideas, was also in the works in Chicago under the direction of Fred Hampton-Deputy Chairman of the Illinois State Chapter of the BPP, that would come to be known as the Rainbow Coalition of Revolutionary Solidarity. In these ways, the approach of the BPP in structuring its alliances with other communities of color and white communities was part of a historical genealogy that began largely with SNCC.

\section{The Politics of Liberation}

Eldridge Cleaver identified Stokely Carmichael, Chairman of SNCC from 1966-1967, as having a particular influence on the BPP's thinking in regard to coalitions. Carmichael and Hamilton's work, Black Power: The Politics of Liberation in America (1967), published before Cleaver's speech in 1967, points to a genealogy of 
autonomous-affiliate organizing. The chapter "Myths of Coalition" is particularly instructive. Carmichael and Hamilton wrote:

There is a strongly held view in this society that the best-indeed, perhaps the only - way for black people to win their political and economic rights is by forming coalitions with the liberal, labor, church, and other kinds of sympathetic organizations or forces... With such allies, they could influence national legislation and national social patterns; racism could thus be ended. This school sees the 'Black Power Movement' as basically separatist and unwilling to enter alliances. SNCC has often stated that it does not oppose the formation of political coalitions per se; obviously they are necessary in a pluralistic society. But coalitions with whom? On what terms? And for what objectives? All too frequently, coalitions involved black people have been only at the leadership level; dictated by terms set by others; and for objectives not calculated to bring major improvement in the lives of the black masses.

Within this analysis, Carmichael and Hamilton sought to define Black Power as a philosophy rooted in self-determination and coalition and refused to accept the prevailing notion that the Black Power movement was racially separatist in its approach. However, Carmichael and Hamilton were cautious to adopt the theory and practice of integrated organizations whole-heartedly because of the history of white racism within the multiracial Left. They identified tokenistic relationships of black people in integrated coalitions with whites in the past and cautioned against alliances that did not translate into material changes in the lives of black people.

The BPP, under the leadership of Newton, Cleaver, Hampton, and others also understood this reality and likewise advocated a similar Black Power stance. They argued for coalitions with whites and other people of color, but coalitions that were governed by specific terms and objectives. After the turn to Black Power, SNCC and the BPP desired alliances that were strategically multiracial-alliances that shifted the goal of the movement from integration to ending imperialism and white supremacy. Many proponents of Black Power argued that integration did not necessarily mean an end to white supremacy. Accordingly, Carmichael and Hamilton observed:

One of the most disturbing things about almost all white supporters has been that they are reluctant to go into their own communities - which is where the racism exists - and work to get rid of it... Where possible, they might also educate other white people to the need for Black Power. The range is great, with much depending on the white person's own class background and environment.

Reiterating the directive of black leadership in SNCC for whites to organize in the white community against racism, Carmichael and Hamilton further defined the role of whites. In their analysis, white people should utilize their personal backgrounds to teach other white people of similar backgrounds about the need for Black Power, and further, to reach out specifically to whites who were empathetic to the project for civil rights but unwilling to organize in the white community. Here, Carmichael and Hamilton recognized the range of work that could be accomplished by white people from a variety of class and social backgrounds in organizing their own constituency within the white community. They also identified connections between antiracism 
and anti-imperialism in the prospect of whites organizing other whites against racism. They wrote:

On a broader scale, there is the very important function working to reorient this society's attitudes and policies toward African and Asian countries. Across the country, smug white communities show a poverty of awareness, a poverty of humanity, indeed, a poverty of ability to act in a civilized manner toward nonAnglo human beings. The white middle-class suburbs need "freedom schools" as badly as the black communities. Anglo-conformity is a dead weight on their necks too. All this is an educative role crying to be performed by those whites so inclined.

The organizing model of black-led Freedom Schools, propagated by the Highlander Center and key in politicizing and mobilizing blacks across the South for civil rights, was repackaged here by Carmichael and Hamilton as a potential model for the development of white antiracist consciousness. Just as black teachers fanned out across southern states to develop neighborhood-level "schools" for the purposes of education and organizing prior to the civil rights movement, Carmichael and Hamilton saw the potential for white radicals to use this model in transforming racial consciousness in the white community. The original Freedom Schools synthesized antiracist education and antiracist organizing by linking teaching with community mobilization. With Freedom Schools as an arm of the civil rights movement, education became a vehicle for movement-building. The mode of education was used as an organizing strategy among southern blacks, helping to identify racial oppression for individuals, collectivize the black experience, and mobilize black communities in an effort to demand change.

In a similar manner, Carmichael and Hamilton identified elements of the white supremacist system that caused suffering for whites as an attempt to bolster white investment in combating institutional racism. Carmichael and Hamilton surmised that while white supremacy produced material or economic wealth for whites (i.e., white privilege), the white supremacist system also produced a poverty of awareness, humanity, and civility in whites towards people of color. Carmichael and Hamilton articulated that the combination of education and organizing for moving blacks through internalized white supremacy in civil rights struggles could likewise be used to move whites through a different, but related process, toward antiracist consciousness.

They outlined the role of organization in such a movement-building process as follows:

It is hoped that eventually there will be a coalition of poor blacks and poor whites... and we see such a coalition as the major internal instrument of change in American society. It is purely academic today to talk about bringing poor blacks and poor whites together, but the task of creating a poor-white power block dedicated to the goals of a free, open society - not one based on racism and subordination - must be attempted. The main responsibility for this task falls upon whites... Only whites can mobilize and organize those communities along the lines necessary and possible for effective alliances with the black communities. This job cannot be left to the existing institutions and agencies, because those structures, for the most part, are reflections of institutionalized racism. If the job is to be done, there must be new forms created. Thus, the political modernization process must involve the white community as well as the black. 
Carmichael and Hamilton utilized the notion of a "power block" to describe how social power is developed through organizing, that is, through the consolidation of numbers of people involved in organizational work to move a specific cause or agenda. They made a call in 1967 for a white power block that could challenge structural racism. Taken up by BPP organizers, this nonracist notion of "white power" was built not on a white supremacist ideology but rather upon the notion of antiracist organizing and the potential for white people to build antiracist power in white communities. Further, Carmichael and Hamilton argued that "new forms" of organization, beyond established institutions, be built for the recruitment, politicization, and mobilization of blacks and whites against the white supremacist system. Because of the racism endemic to most formalized institutions in the USA, Carmichael and Hamilton called for a making and remaking of community structures that could organize a new racial reality in the USA. What these structures might be, and how they might function, is the subject of the next section.

\section{Message from the Grassroots}

According to radical activists at the time, grassroots organization was one proven alternative to established institutions for providing for the needs of everyday people. When politically focused toward antiracism, and aligned strategically with multiracial coalitions, the promise of such grassroots efforts could be realized - as seen with SNCC and SSOC, the BPP and the Peace and Freedom Party, and the Rainbow Coalition. Such alliances involved Black Power organizations working side-by-side with antiracist white organizations and other organizations of color. For SNCC and the BPP, this was not seen as a contradiction; instead, this approach was considered strategic. Working with non-black organizers was not the problem for Black Power organizations, according to SNCC and the BPP. Their central concern was how, and under what circumstances, could Black Power organizations work with whites. Carmichael and Hamilton articulated a nuanced approach to working with whites in the movement:

It is our position that black organizations should be black-led and essentially black-staffed, with policy being made by black people. White people can and do play very important supportive roles in those organizations. Where they come with specific skills and techniques, they will be evaluated in those terms. All too frequently, however, many young, middle-class, white Americans, like some sort of Pepsi generation, have wanted to "come alive" through the black community and black groups. They have wanted to be where the action is - and the action has been in those places. They have sought refuge among blacks from a sterile, meaningless, irrelevant life in middle-class America. They have been unable to deal with the stifling, racist, parochial, split-level mentality of their parents, teachers, preachers and friends (Carmichael and Hamilton 1967).

In Hamilton and Carmichael's analysis, SNCC organizers were not against multiracial organizations. They understood that the leadership and direction of black organizations 
should be black, but that whites and other people of color could support this work. However, non-blacks would not lead. Carmichael and Hamilton observed the tendency of some whites to join black organizations for the wrong reasons. Fleeing the white racism of their home communities, white activists were simultaneously fleeing the responsibility of transforming the consciousness and action in white communities towards antiracism. A broader understanding of a multiracial movement can be found in Carmichael and Hamilton's analysis. They understood that a mass-based effort to challenge white supremacy could be multiracial without necessarily taking place through multiracial organizations.

Whites working to "deal with the stifling, racist, parochial, split-level mentality of their parents, teachers, preachers, and friends" was a crucial contribution to a multiracial movement, according to Carmichael and Hamilton. Whites organizing whites against racism created the possibility for racism-free, multiracial coalitions and alliances to occur. SNCC and the BPP argued against the rush to integrate, not only society, but social movement organizations. Racially separate organizing did not seek to reify segregation, but rather to end segregation through strategic political uses of race. Through this strategy, both whites and people of color could depend upon one another to deliver numbers of people to movement organizations working against white supremacy. Carmichael and Hamilton reflected on the promise and power of such a model:

Ultimately, the gains of our struggle will be meaningful only when consolidated by viable coalitions between blacks and whites who accept each other as co-equal partners and who identify their goals as politically and economically similar. At this stage, given the nature of the society, distinct roles must be played. The charge that this approach is "anti-white" remains as inaccurate as almost all the other public commentary on black power.

This final stance on coalition in the book Black Power: The Politics of Liberation in America couched Black Power in terms the BPP would later articulate: Black Power was people power. Far from an anti-white ideology, Black Power sought radical transformation of individuals, communities and institutions across race toward an antiracist, antiimperialist, pro-people USA. For whites and other people of color to join the movement, however, they would need to challenge not only the racist power structure but racism within their own selves and communities. This position, however, would require a radical vanguard that was willing to posit and practice such controversial ideas.

\section{The Roles of the Vanguard}

Historian Jeffrey O.G. Ogbar wrote that the Black Panther Party existed as a "vanguard party," (Ogbar 2006) and organizations such as the Puerto Rican Young Lords and the white Young Patriots followed the lead of the Panthers in many ways, including mirroring their organizational infrastructure, program, and platform. The Chairman of the Young Lords, Jose "Cha Cha" Jimenez supported this claim at the time, explaining that, "as we read and study other organizations... we see and we recognize the Black Panther Party as a revolutionary vanguard. And we feel that as revolutionaries we should follow the vanguard party." (Ogbar 2006, 267). Ogbar noted that the Lords and 
Patriots, similar to the BPP, held political-education classes, offered free breakfast programs to children, and monitored the police. Organizational structure and titles also echoed those of the Panthers', including Ministers of Information, Defense, Education, and a Central committee with field marshals. Inspired by the BPP's ten-point program (Black Panther Party 2002), the white Young Patriots adopted an eleven-point program, and the Young Lords had a thirteen-point program. Huey Newton explained the BPP as a vanguard organization:

We say that black people are the vanguard of the revolution in this country, and since no one will be free until the people of America are free, that black people are the vanguard of world revolution... We believe that black Americans are the first real internationalists; not just the Black Panther Party but black Americans. We are internationalists because we have been internationally dispersed by slavery, and we can easily identify with other people in other cultures. Because of slavery, we never really felt attached to the nation (The Movement 1968).

The BPP's leadership as a vanguard party clearly influenced white revolutionaries. The Patriot Party described itself as "a revolutionary Party for poor and oppressed white people" (Foner and Carson 2014, 239). and sought to represent this constituency in the broader movement in the late 1960s and early 1970s. Leveling critiques at the "so called white "movement" including "radical groups," the Patriot Party remained focused on alliances with the BPP and Young Lords. "We're talking about Brothers and Sisters who stand in solidarity, who go down together," the Patriots wrote, citing the past Panthers, Patriots, and Lords who had been killed or murdered by police action. "Nobody calls us Brother unless they can take that step [to be killed] - that's solidarity!" (Foner and Carson 2014, 239).

The Young Patriots drew a narrow definition of solidarity here, critiquing previous white activists who defined solidarity across a spectrum of service and alliance relationships with radical organizations of color. The largely campus-based activism of Students for a Democratic Society, the Southern Student Organizing Committee, and other white solidarity activists frustrated the Patriot Party. Calling such work "petty bourgeoisie" and recognizing that many members of such groups have "had all the education, had all the schooling", the Patriots identified a class cleavage among white radicals involved in movement work at the time. Similar to Black Power critiques of integrationist approaches to the civil rights movement, class became a heavy dividing line for the Patriots - not only in societal structures, but in approaches to movement and organizing work as well. Integration as the ultimate goal-in society and movement organizations - began to be questioned by radical organizers, white and of color.

\section{An Integrated Movement?}

Proponents of integration as a goal of the modern civil rights movement in the late $1950 \mathrm{~s}$ and early 1960s often reflected this sentiment in their organizing strategy, as well. Community organizations working for civil rights then were often multiracialintegrated with whites who were sympathetic to the cause. SNCC took up this approach in its formative years (1960-1964), modeling the "beloved community" imagined by 
Dr. Martin Luther King, Jr. Following the rise of Black Power politics with Malcolm X, and his subsequent assassination in 1965, SNCC re-evaluated its integrationist approach and turned toward black self-determination, removing whites from the organization in 1966. The Black Panther Party became another Black Power organization when it formed the same year in Oakland, CA. These organizational developments marked a turn in movement rhetoric toward poor black people specifically, and poor people generally. King considered this the "second phase" of the modern civil rights movement and sought to incorporate the concerns of Black Power into a larger poor people's and human rights agenda. He wrote, "We have left the realm of constitutional rights and we are entering the area of human rights" (King et al. 1986, 3, 138). King wrote the book, Where Do We Go from Here: Chaos or Community in 1967, the same year Carmichael and Hamilton published Black Power: The Politics of Liberation in America.

In his text, King recognized the power of multiracial alliances of the poor, as Carmichael and Hamilton had. King wrote:

Negroes have irrevocably undermined the foundations of Southern segregation; they have assembled the power through self-organization and coalition to place their demands on all significant national agendas. And beyond this, they have now accumulated strength to change the quality and substance of their demands. From issues of personal dignity they are now advancing to programs that impinge upon the basic system of social and economic control. At this level Negro programs go beyond race and deal with economic inequality, where it exists. In the pursuit of these goals, the white poor become involved, and the potentiality emerges for a powerful alliance... Negroes hold only one key to the double lock of peaceful change. The other is in the hands of the white community (King et al. 1986, 17, 23).

This sentiment by King developed organizationally into the Poor People's Campaign, a project headed by the Southern Conference Leadership Conference in 1967 which planned to pressure Congress to draft and pass an Economic Bill of Rights to benefit poor US residents. King was assassinated before this project could fully develop. However, in Where Do We Go From Here, he identified a crucial component that would shape the success of such a movement: the lever of whites organizing against racism. King wrote:

Negroes have proceeded from a premise that equality means what it says, and they have taken white Americans at their word when they talked of it as an objective. But most whites in America in 1967, including many persons of goodwill, proceed from a premise that equality is a loose expression for improvement. White America is not even psychologically organized to close the gap - essentially it seeks only to make it less painful and less obvious but in most respects to retain it. Most of the abrasions between Negroes and white liberals arise from this fact (King et al. 1986, 17, 8).

The lack of psychological or formal organization in the white community to close the gap between the rhetoric and reality of equality for blacks was of particular concern for King. He noted the particular difficulties that arose between blacks and white liberals in this respect; in essence, he conveyed a longstanding historical critique of the liberal white Left which often stood aside in the face of white racism. With hope, however, 
King identified the ways that the civil rights struggles of blacks had potentially ushered in a second phase of the civil rights movement that could incorporate human rights and economic rights for all people, white and of color. Regrettably, he saw little to no effort coming from the white community to organize such efforts within an explicitly antiracist framework.

The white Patriot Party in Chicago existed as a radical exception to this rule at the time, articulating and acting on their role as white people in a revolutionary, multiracial movement. Far from identifying as liberal, their brand of politics sought a revolutionary movement in the USA in alliance with radical organizations of color. Of their ideological relationship to the BPP, the Patriot Party wrote the following:

Most of the so-called "movement" states that they recognize Brothers and Sisters of the Black Panther Party as the Vanguard Party-however, they do not follow their ideology and practice. The Patriot Party recognizes the Black Panther Party as the Vanguard by our practice. The people learn by observation and participation. The "movement" doesn't even recognize that we exist. They are racist toward oppressed white people (Foner and Carson 2014, 241).

Inspired by the BPP, the Young Patriots put forth an analysis of the white supremacist system that articulated its toll on whites, as well as people of color. They critiqued the mainstream white Left, in particular, for ignoring the needs of poor people across race. The Patriots wrote, "We recognize that the struggle here in Babylon is a class struggle; the haves against the have nots; the oppressed against the oppressor, and the exploited against the exploiter." Different from a strictly class-based understanding of political economy, the Young Patriots understood the particular role people of color, namely the Black Panthers, in rallying resistance against the white supremacist and capitalist systems. They likewise understood the role of whites in aligning with the poor and working-class people of color through an explicitly antiracist approach.

The Patriots' accusations of "racism toward oppressed white people" could be initially read as an antecedent of "reverse racism" ideology, however, the Young Patriots critiques were aimed at the liberal white Left, whom they saw abandoning poor whites and revolutionaries of color alike. Their critiques of the liberal white Left echoed critiques of mainstream civil rights organizations by proponents of Black Power like SNCC and the BPP, who felt some organizations had distanced themselves from the poor of all colors. This nuanced reading of racism within the liberal white Left by the Young Patriots makes apparent the fiction of a politically homogenous white community. Accusations of white-on-white racism reveal an ideological separation among the white Left at the time, in terms of understandings of class and race.

The Young Patriots wrote, "The Patriot Party comes from the people who have been down, and when you're down, the only place to go is up toward freedom, and anybody who stands in our way, and tries to stop us, is the enemy" (Foner and Carson 2014, 241). The Young Patriots were an example of a revolutionary poor white cadre organization aligning with revolutionary poor cadres of color against the white supremacist and capitalist systems, and against those of all colors who failed to center the struggles of the poor. The work of the Young Patriots, in alliance with the Rainbow Coalition, is instructive in considering the roles of whites in revolutionary, antiracist contexts. 


\section{Antiracist Patriots}

The Young Patriots worked in the Uptown area of Chicago, a "Port of Entry" for mostly southern whites, in the 1960s and early 1970s. The organization worked as part of a larger multiracial strategy to radicalize, as well as serve the material needs, of people across race in the Chicago area. According to the Young Patriots this work represented "black, brown, and white groups working in a coalition to educate the people" in their respective communities (Franklin 1971, 110, 112). In 1970, they claimed chapters across the USA and adopted the "Ten Point Platform and Program" of the Black Panther Party that made demands including freedom for black people to "determine the destiny" of the black community and "full employment...decent housing...education... and an end to police brutality and murder of black people" (Foner 1970, 2).

The Young Patriots also engaged in "serve the people" projects like the BPP, such as a free clinic, free breakfast programs and other community service projects (Goodman 1970). For example, the Patriots' Eugene, Oregon chapter fed breakfast to about fifty children, ran a liberation school, and organized a firewood co-op for mountain families using wood stoves. The Patriots mirrored the Panthers commitment to community control over community institutions: "We don't want to run this clinic for the people we want them to learn how to run it and take it over," one Patriot from the Yorkville, New York chapter told a local reporter in 1969 (Goodman 1970). This work by Rainbow Coalition organizations served the material needs of the community and was valuable to local residents in and of itself, but the work also functioned as a political strategy to reveal the failure of city, state, and federal government to adequately provide for people across race. In this way, the serve-the-people programs were used by the Black Panther Party, the Puerto Rican Young Lords, and white Young Patriots as organizing tools - to politicize, recruit, and mobilize everyday people toward revolutionary ideology and practice. The Patriots read such works as Millhands and Preachers, Tom Watson, Agrarian Rebel, and Black Reconstruction in America by W.E.B. Du Bois (Goodman 1970), revealing a study-and-struggle ethos practiced by the group that drew inspiration from people from a variety of race and class backgrounds.

Elbert "Big Man" Howard spoke on the Rainbow Coalition and the work of the Young Patriots at the 40th Anniversary of the BPP in Oakland, CA in 2006:

The Patriots were a group of white working-class and poor young people which originally formed in Chicago and many of them originated from street-turf gangs. Their chapters and Ten Point Program were modeled after the Black Panther Party's and they were strong supporters of the Black Panther Party. They closely followed the Black Panther Party's example and dedicated themselves to serving the basic needs of their communities, such as feeding hungry children with free breakfast programs. Many worked to establish free health clinics and other services in their communities. The Patriot Party, like the Panthers, published a newspaper (Howard 2006).

The antecedent of the Young Patriots in the Uptown area of Chicago was a project started by the Students for a Democratic Society called Jobs or Income Now (JOIN). This worked triggered a national debate in movement work on the question of white 
resistance to the white supremacist system. Coalescing in a series of articles in The Movement newspaper (a news organ initiated by SNCC), the discussion began with a lengthy article in the November 1967 issue entitled "We've Got to Reach Our Own People: A Plan for White Resistance."

The introduction of the piece noted that "what a year ago [1966] was merely a slogan has begun to take shape...this article outlines a program of resistance; it seeks to clarify objectives and describe a way in which part of the resistance can root itself in poor white and lower paid working class communities; it attempts to suggest the urgency, need and potential for establishing those roots now." The Movement, a newspaper originally funded by the Bay Area chapter of Friends of SNCC, most likely referenced 1966 as a pivotal year for the white Left to reflect on its role in movement-building as a result of SNCC's decision that year to remove whites from its leadership - encouraging whites to organize other whites against racism instead (The New York Times 1966). The focus of the initial article on "White Resistance" was on organizing the white working-class against the Vietnam War, and echoed existing anti-war organizing that had begun around 1963. This was a shift from discussing white support for people of color struggles within US borders - as with the work of Students for a Democratic Society, and the Southern Student Organizing Committee in relation to SNCC.

The article framed the current social conditions under the rubric of racism only briefly, arguing that "unchallenged racism and patriotism (anti-communism)" was shared both by "the people most brutalized by material and social exploitation" and "white America" and admittedly "must be broken if a movement is to succeed." Analyzing racism and anti-communism as tenets equally shared by people of color and white people side-stepped the analyses of radical black organizers, like Stokely Carmichael and Huey Newton, who argued for white responsibility for white supremacy and racism, and self-determination in the black community. The "White Resistance" article hinted at a larger trend in the radical white Left at the time that would set a precedent for white activism in years to come: explicit challenges to the white supremacist system within US borders set aside in favor of (at best) solidarity with revolutionary people of color in Third World countries.

The notion of "resistance" intentionally took the place of "revolution" in this article, according to the authors. They wrote, "indeed we call this a resistance, not a revolution, because entrenched power is too strong to be broken." This article seemed to announce to the white Left in 1967 an end to revolutionary engagement with systems of power at the same time the Black Panther Party was inspiring selfdetermination in black communities and other communities of color nationwide. The analysis by Black Power advocates like Carmichael and others that black people were connected to Third World colonies in a common struggle against white oppression became lost on many in the liberal and radical white Left at the time. While the Black Panthers, Young Patriots, and Young Lords in Chicago made connections between police repression at home and US military surges abroad, developed local serve-the-people programs, and sought freedom for colonies both internal and external to the USA, the majority of politically active whites in the USA focused their energies on draft resistance to the Vietnam War. What, if anything, were many whites and people of color missing from organizational formations such as the Rainbow Coalition at the time? 


\section{Black, Brown, White Power}

The strategies, sights, and sounds of the Rainbow Coalition were extraordinarily unique, if not uncanny. Their united call for "Black Power, Brown Power, White Power'35 extended the Black Power philosophy into a multiracial cadre of workingclass revolutionaries and put contradictions of movement politics front and center. A reporter, Barbara Joyce, in 1969 got a rare glimpse inside the Rainbow Coalition, and specifically the work of the Young Patriots. Visiting the Patriots' Yorkville, New York chapter, Joyce received a history of the organization, as well as an on-the-ground understanding of their theory and practice. She reported for the Liberation News Service, a grassroots movement newspaper at the time, the following,

Patriots showed me pictures of a rally held in Chicago jointly with the Panthers. A Confederate flag hangs behind the podium next to the Panther flag. Another slightly tattered Confederate flag on the wall behind us belonged to the Patriot Party Chairman's family. "It was actually flown in battle," boasts Roger, who looks about 17 but has worked with the Patriots "from the beginning" when they were a newly politicized gang of street kids in Uptown, Chicago (Goodman 1970).

The Confederate flag, also known to be pinned on Young Patriots' berets, signified the pride the white Appalachians had in the South at the same time they proclaimed solidarity with the BPP. A similar symbolism arose in the Southern Student Organizing Committee (SSOC) a few years earlier, in 1964, in their alliance with SNCC. Their logo depicted a black and white hand clasped over a Confederate flag. SSOC, as well as the Patriots, attempted to recoup southern pride and tradition in a way that served radical, multiracial organizing against white supremacy. SSOC's attempts at producing visuals that portrayed a "building of a New South, and a vision of the democratic and integrated South" (SSOC 1964) with the Confederate flag fell flat, however, fomenting division within the organization's ranks.

The Young Patriots also had difficulty with their imagery resonating beyond the boundaries of their organization or the Rainbow Coalition. From the perspective of many radicals, the imagery of the BPP and Confederate flags flying together seemed incompatible; however, for Black Power groups such as SNCC and the BPP, such imagery was not discussed as obstacles in their organizing work. In fact, the Patriots used the Confederate flag as a symbolic bridge to recruit many southern whites and move them toward antiracist consciousness and action. The Patriots differed from the Southern Student Organizing Committee in its constituency. SSOC, a largely middleclass student organization, stood in contrast to the Patriots' membership and recruitment of poor whites. Patriots' Defense Captain, Art Turco, said this, "We're concerned with our people, the oppressed whites, those who haven't even made it into the working class yet... We're into organizing the lumpen-proletariat, the black and white niggers, that's us" (Goodman 1970).

Whereas, Turco was imperfect in his conflation of black and white racial histories in his use of the term "nigger" to describe both poor whites and blacks, his comments revealed the ways that the Patriots thought about class and capitalism through the lens of race, racism, and white supremacy. It also showed the flexibility of the BPP to build coalitions with white revolutionaries who were not perfect in their 
ideological articulations and was a testament to the resiliency of relationships across race within radical organizing. Turco's phrasing of “organizing the lumpen-proletariat" also showed the influence of the BPP on the Patriots understanding of political economy and the revolutionary potential of those that Karl Marx otherwise considered "refuse, offal and wreck of all classes" (Marx 1913, 83).

At the time of Joyce's contact with the Patriots in December of 1969, they were planning an "organizing tour of the South", which they hoped to make the main focus of a "national revolutionary white community." noted other visuals at the Yorkville Young Patriot chapter, "Roger's black cowboy hat bears two Patriot buttons, beside the stars and bars. One button shows two upraised red fists breaking handcuffs; the other reads: 'Resurrect John Brown.' Around us on the walls, among the posters of Che and Panther martyrs, hang leaflets offering free medical care to the people of Yorkville, and urging tenants to band together "against all pig landlords." (Joyce 1970) These visuals indicated the importance of social movement history to the efforts of the Young Patriots and showed the symbols that inspired multiracial alliance and antiracist organizing work within their organization.

Scholars Schnell, Terkildsen, and Callaghan discuss the politics of such metasymbols in their article "Symbolism and Social Movements: How U.S. Political Debates Are Shaped and Citizens' Attitudes Influenced by Symbolic Communiqués" (Schnell et al. 2000). They described meta-symbols as "condensing symbols...defined as those labels that evoke broad categories of meaning and strong affect, that is they are low in cognition and dominated by emotions" (227). They argued that such symbols, overpopulating media coverage of social movements in the 1970 s led to, at best, cursory understandings of the organizations or groups involved in such movements, and at worst misrepresentations of the movement and its supporters. It is in this vein that such symbolism for the Patriots and other radical groups often stood in for larger, ideological discussions which explained the motives and reasons behind their day-today work.

Media coverage or scholarship that glossed over the political nuances of movement organizations' approach, in favor of the spectacle of movement symbolism, could easily paint the Patriots and the rest of the Rainbow Coalition as groups on the fringe of society - rather than organizations which advocated for the majority of US. residents, including the poor and working-class. In media coverage of the movement, references to leaflets offering free medical care or encouragement to tenants to organize for their rights, often lost a symbolic battle to imagery invoking history-laden terms such as "handcuffs" and "pigs," "John Brown" and "Che." The imagery selected by Joyce to describe the Patriots spoke loudly of "revolutionary violence," (Joseph 2006, 240), a term used by Black Power advocates such as SNCC, Malcolm X, and the BPP in the years prior to the formation of the Patriots.

"We are for revolutionary violence," Stokely Carmichael told the students at San Jose University: "We are for spitting to killing, whatever is necessary to liberate us" (Joseph 2006, 240). Carmichael's statement echoed the oft-quoted words of Malcolm $\mathrm{X}$, "by any means necessary," and was also heard in the words of the BPP. Huey Newton had said, "Only with the power of the gun can the Black masses halt the terror and brutality perpetuated against them by the armed racist power structure" (Rushdy 1999, 46). Despite the fact that these organizations advocated much more than armed 
revolution, meta-symbols of revolutionary violence came to define radical organizing in the mind of the general public. A nuanced understanding of the ideology and practice of these groups behind the imagery was less common. Reading the imagery in the Yorkville chapter of the Young Patriots, however, offers such nuance. Patriot logos sat next to the Confederate flag, complicating notions of patriotism and nationalism.

This was Southern pride articulated within a revolutionary, white antiracist organization that sought the overthrow of white supremacist capitalism. Furthermore, the Patriots exaltation of John Brown, the famed white abolitionist who died in an effort to lead a slave rebellion against the Federal Arsenal in Harper's Ferry, West Virginia in 1859 sat side-by-side with Che Guervara and martyrs of the BPP, drawing a historical arc across race, space, and time. This imagery in the Yorkville chapter produced a lineage of multiracial and revolutionary activism in which the Patriots also saw themselves. The organizations in the Rainbow Coalition were adept at not only the political uses of race, but the political uses of image. Their use of images and "scenes" were documented in 1968 by a young film maker and his team in two related films that came to be known as American Revolution 2 and The Murder of Fred Hampton.

\section{American Revolution 2}

Rare footage of the Young Patriots and Black Panthers involved in on-the-ground organizing work in Uptown in Chicago was depicted in the documentary American Revolution 2, filmed in 1968, in the aftermath of the tumultuous Democratic convention. It was given four stars (the top rating) by film critic Roger Ebert in 1969, who wrote this in his Chicago Sun-Times column:

American Revolution 2 shows this much clearly: in the aftermath of the Democratic convention, a group of formerly voiceless, even opinionless Uptown whites become galvanized into a community that was fed up. That these people were able to understand that their enemy was not the black man (or another stand-in target) but an establishment that dismissed them as poor hillbillies and, therefore, less than equal. That these people formed an alliance with the Black Panthers, borrowing their methods and organization and protest. And that this alliance has created, in the midst of a city largely without a voice (unless you're white, unless you're educated, unless you're affluent, unless you have clout), a community that founds its voice and used it (Ebert 2007, 31).

American Revolution 2 fell shy of national impact, but it detailed an otherwise quiet chapter of the 1960's Black Power era - the realities of autonomous-affiliate organizing that sought to connect poor people across race in efforts that challenged the institutional manifestations of both white supremacy and capitalism. Ebert saw the importance of the film, and the Patriots and BPP's alliance which it documented, but few movement scholars or history books have raised the filmic moment to any special prominence. Few historical or contemporary sources offered the striking detail of the organizing work of the Rainbow Coalition that the film provided.

American Revolution 2 involved no narrator, but instead showed film clips of an assortment of street protests, strategy sessions, and at least three community meetings 
in which the Patriots and Panthers worked together to organize white residents of Uptown. Central to the footage is Black Panther member, Bobby Lee, who some credit with the naming of the multiracial alliances with the BPP in Chicago as "the Rainbow Coalition." An interview with Bobby Lee by author and activist James Tracy provided some insight into the beginnings of the Rainbow Coalition (Tracy 2006). Lee was a member of SNCC before becoming a Section Leader of the BPP in the Uptown Section of Chicago - a similar story for many involved in SNCC and another testimony to the genealogy that connected these organizations. Lee became one of the lead organizers of the BPP in their coalition with the Young Patriots and the Young Lords. Tracy asked him about his work with the Patriots,

Tracy: In Chicago, you formed the first Rainbow Coalition with the Young Lords and the Young Patriots organization. Was this controversial in the Black Panther Party? I don't think it could have been easy for Black Radicals to accept working with whites who wore the Confederate Flag on their uniforms.

Lee: ...Many of the Panthers left the group when we built alliances. Some didn't like the Patriots, some just didn't like white people in general. They were heavy into nationalism. To tell the truth, it was a necessary purging, except [they] took themselves out of the organization. The Rainbow Coalition was just a code word for class struggle.

Lee's words reflect an uneasy tension within the ranks of the BPP regarding the roles of whites. This mirrored a similar tension that emerged a few years earlier among black organizers in SNCC, when the idea of removing whites from the organization was raised. Lee credited two organizations, Rising Up Angry and JOIN Community Union in priming Uptown for radical organizing of whites by the Patriots. These organizations, outgrowths of the Education and Research Action Project (ERAP) of the Students for a Democratic Society in 1963, sought to organize and engage white people around issues of race and class in white communities to bolster white support for the civil rights movement. As Tracy documented in another article with author and activist, Amy Sonnie, "SDS recruited students to work in cities like Cleveland, Chicago and Newark to 'organize people around their felt needs' with the strategy of building an interracial movement of the poor - a northern upsurge - that could eventually be united with the Civil Rights Movement" (Sonnie and Tracey 2008). JOIN (Jobs or Income Now) in Chicago was the longest lasting of the ERAP projects, and set the precedent for white organizing against racism and capitalism in Uptown prior to the Patriots work in the late 1960s.

One JOIN organizer, Peggy Terry, remembered that by the time Stokely Carmichael and SNCC made the more vocal call for whites to leave SNCC and 'organize their own' in 1966, JOIN had already made inroads transforming poor white participation in the New Left (Tracy 2006). Bobby Lee recalled the tensions inherent in the Young Patriots organizing of the white community in Uptown Chicago, where white revolutionaries vied for the hearts and minds of whites against white racists who were also organizing. He said, "The Uptown neighborhood was prime recruiting zone for white supremacists. Most of the cats who were in the Patriots also had at least one family member in the Klan. Cats like Mike James and Junebug, and Tappis worked hard to fight that mentality. Mike James and RUA drove a wedge in that bullshit, that white 
supremacist bullshit, their groundwork was just amazing, out of this world" (Tracy 2006).

Lee's recollections revealed the manner in which whites organizing whites in many cases directly confronted the organizing efforts of white supremacists. In the absence of a white antiracist organizational presence, many of the Uptown residents would have been prime targets for recruitment of the Ku Klux Klan. The notion of driving a "wedge" in the white community to interrupt the consolidation of explicit or implicit white supremacist ideology and practice is an idea taken up by white antiracist organizations at other times in US history including the Southern Student Organizing Committee, the Motor City Labor League, the Weather Underground, Prairie Fire, and in a contemporary context, Showing Up for Racial Justice. I turn to this theoretical and practical approach to organizing now.

\section{Drawing the Lines}

Creating a crisis of conscience in the white community has been a tried and true strategy for work against racism in the white community, from white abolitionists' efforts against slavery to organizing work by the Patriots in Uptown. The drawing of a political line in relation to racism in the white community produced a point of contention for white antiracist organizers, which they utilized for politicization and mobilization of other whites. Organizers of color involved in civil rights organizing had drawn similar political lines in the white community, asking whites to take a position on contentious issues such as segregation of public schools and public places, and voting disenfranchisement of blacks. The approach was later taken up by white allies in an effort to organize their own communities. The white organizer was tasked with convincing other whites of the importance of challenging the white supremacist system, and to supporting people of color in their efforts to challenge the racial state. This political approach was often developed from within multiracial alliances.

Bobby Lee's incremental work to build up a BPP alliance with the Patriots led to the formalization of the Rainbow Coalition. Lee recalled the first time he met the Patriots:

It was at the Church of the Three Crosses. There was a meeting, and it was the one recorded in the movie American Revolution II. After the crowd left, the Patriots were still there. We asked the Minister if he could let us have his office. We asked the Patriots if they could work with the Panthers and they say yes. I didn't even tell Fred [Hampton] for the first three weeks of meeting with these cats. It wasn't easy to build an alliance. I advised them on how to set up "serve the people" programs - free breakfasts, people's health clinics, all that. I had to run with those cats, break bread with them, hang out at the pool hall. I had to lay down on their couch, in their neighborhood. Then I had to invite them into mine. That was how the Rainbow Coalition was built, real slow. Then I contact Cha Cha Jimenez from the Young Lords (Tracy 2006).

Lee's descriptions show the involved process of organizing and developing revolutionary projects across race. Noteworthy, is that organizing is translated here by Lee as relationship-building with political and strategic goals. BPP and Patriots members were 
in each other's lives before an organizational alliance was built. The Rainbow Coalition grew out of strategic relationships across race which led to a cadre of revolutionary organizers in various racial communities. The BPP trained the Patriots in "serve the people" programs with the intention that the Patriots would take up this work autonomously, while being affiliated with the BPP in the larger project of challenging manifestations of white supremacy and capitalism. Couching their radical organizing efforts in what otherwise would be characterized as "social service" or "advocacy" work, the BPP, Patriots, and Young Lords established a base of trust in the communities they sought to recruit, politicize, and mobilize through programs that met people's basic needs. This required close relationships, not only among the organizational leadership, but among the leadership and the communities these groups served and sought to organize.

Scenes from American Revolution 2 revealed this early work among the BPP, the Patriots, and the white community in Uptown. The opening scenes depicted BPP members mingling with members of the Patriots in the Patriots' Uptown office at the Church of Three Crosses - the meeting referenced by Bobby Lee. Discussions of gentrification of poor white neighborhoods are discussed among a few Patriots, as the Panthers and other Patriots sat down at a table to meet. "This is poor people's power," an organizer with the Patriots told a group of whites in a community center in Uptown Chicago in the next scene. "That's what this little campaign and button's all about that we've been passing around to people," he says holding up a Patriots' pin. "People that want to take over and have a government for themselves, that they'll be treated right. That's what it's all about." The Patriot leader, whose name is not disclosed, then introduces Bobby Lee of the Chicago Chapter of the BPP. "I want to introduce a man that came over tonight from another part of town" (American Revolution 2 2007; 1969).

The camera pans to Bobby Lee, in a black beret and leather jacket. "But he's fighting for some of the same causes we're fighting for," the white Patriot member says. Bobby Lee: "I'm a Black Panther, a section leader of the Black Panthers...We met with Junebug and his brothers [of the Patriots] last week...The Panthers are here. Are here. Panthers are here...for Uptown." An audible, questioning "Okay?" is heard from the all-white audience. Lee continued, "for anyone that lives in Uptown... When I say "The Panthers are here,' you have to tell us what we can do, and what we can do together. We've come here with our hearts open, and you cats supervise us, where we can be of help to you" (American Revolution 2 2007; 1969). This moment may be of surprise to those that know Black Panther history-here a leader in the BPP advocated that the white community literally supervise Black Panthers. As Lee mentioned previously, these were all strategic maneuvers to gain trust from the Patriots and their white constituency in order to build a multiracial cadre that could eventually organize together against white supremacy and capitalism. These scenes also reveal the trialand-error of community organizing work, where the community often becomes a social change laboratory for committed activists.

After asking who in the room were "concerned people," and getting no response Lee asks, "Who here wants to see this thing move?" and elicits a room full of raised hands. "The first thing we talk about now is how we're going to organize... where we're going to organize," Lee continued. "We all must right now figure out what we want... What do you want? What do you want, man?" Lee approaches one man in the audience, "What do you want in your community?" (American Revolution 2 2007; 1969). The scene follows for the next ten minutes with Lee supporting the Patriots in drawing out engagement from the 
room full of white Uptown residents on the conditions in their community, and what they want to see changed. Notable about these scenes of slow alliance building across race and revolutionary organization is the emphasis on process. Leadership in the BPP and Patriots hung out initially as acquaintances for several days, then met to discuss ways in which the organizations might interface, which then led the Patriots to invite Lee to a white community meeting to help organize the Patriots' constituency.

Whereas race wasn't explicitly named in that community meeting, the common material conditions that white residents and black residents shared was on the table within a revolutionary, antiracist context. As Lee mentioned in an interview later the Rainbow Coalition was "just another word for class struggle" (American Revolution 2 2007; 1969). Their approach was informed by a particular understanding of the ways race and class struggles were intertwined, and they centered strategies to confront racism, capitalism, and imperialism simultaneously. The efforts of the Rainbow Coalition differed from earlier civil rights organizing in that their efforts did not seek multiracial organization, but racially separate organizations that were in alliance, in order to mobilize poor people across race. Huey Newton explained this choice in his interview with The Movement, remarking that the Black Panthers have "NEVER been controlled by white people."

Reflecting on multiracial, civil rights organizations such as SNCC and their relationship with whites, Newton identified that whites "controlled the program of SNCC with money and they controlled the ideology, or the stands SNCC would take." He furthered, "the blacks in SNCC were completely controlled program-wise; they couldn't do any more than these white liberals wanted them to do, which wasn't very much. So the white liberals were not working for the self-determination of the black community" (The Movement 1968, 8-11). Whether or not Newton's observations were entirely accurate regarding SNCC, his assessment of their organization pushed the BPP to be entirely black-led and black controlled.

SNCC's turn to Black Power, however, was a historical refutation of Newton's observations. Under the leadership of Stokely Carmichael, SNCC voted to remove whites from the organization in 1966. This did not eliminate SNCC's desire for coalition with whites - as they stated in organizational documents published in the NY Times - it simply asserted that work by whites to challenge racism in the white community would be required before any formal multiracial coalitions or alliances could be developed. The BPP organized around the question of working with the larger white community by forming an all-black organization from the start. This formation, like the Black Power development within SNCC, did not exclude coalitions with whites it simply allowed the terms of engagement to be controlled by people of color as much as they were controlled by whites. Instead of the challenge being put to people of color to integrate whites into their organizations (at the same time those same people of color struggled to be integrated into the USA), the challenge was put to white people to organize the white community towards antiracism. This work developed from predominantly class-based organizing of the past but sought to challenge white supremacy as well as capitalism.

\section{Black Marxism}

The Rainbow Coalition of Revolutionary Solidarity differed from labor organizing of earlier decades, in that the coalition sought an explicit approach to both race and class 
in their organizing. The work of the BPP and Patriots was both antiracist and anticapitalist. The Patriots organized white people in their respective neighborhoods toward allied struggle with the BPP for the improvement of material conditions in their respective neighborhoods. The Rainbow Coalition's analysis of racism and capitalism was inspired by the BPP and drew from global independence struggles against colonial governments as well as revolutionary worker movements. Huey Newton wrote of the BPP, "We realize that this country became very rich upon slavery and that slavery is capitalism in the extreme. We have two evils to fight, capitalism and racism. We must destroy both racism and capitalism" (Jones 1998, 38).

The BPP also saw itself increasingly as an internationalist organization, connected in radical struggle and solidarity with independence movements around the world. They moved through a variety of ideological positions including black nationalism, revolutionary nationalism, revolutionary internationalism, and ultimately Revolutionary Intercommunalism. They described themselves as "revolutionary internationalists" (Heath 1976, 262). during the early formation of the Rainbow Coalition, transitioning to Revolutionary Intercommunalism (an outgrowth of Internationalism) at the Revolutionary People's Constitutional Convention in 1970. The BPP recognized the USA, not as a nation, but as an empire that extended its boundaries to overtake and exploit the people of the world. They wrote, "If a nation cannot protect its boundaries and prevent the entry of an aggressor, if a nation cannot control its political structure and its cultural institutions, then it is no longer a nation, it must be something else" (Jones 1998, 171). The ideological "answer" for some segments of the BPP became the philosophy of Intercommunalism, where oppressed peoples globally might unite across borders to challenge US empire. This was exemplified by the BPP's solidarity work abroad — with the people of North Korea, North Vietnam, and China - and with their work within US "borders," as in Uptown Chicago.

The Rainbow Coalition practiced both Intercommunalism and solidarity in the late 1960s and early 1970s, but little scholarly attention has been paid to the ways that "oppressed people" under the BPP banner included poor whites as well as people of color, both within and beyond the USA, who worked to challenge white supremacy and capitalism. The Rainbow Coalition not only provided models for autonomous-affiliate organizing across race, but also provided models for autonomous-affiliate organizing across borders. These multiple border crossings in the BPP's political strategy are really best described as "intercommunalism," not only because of the notion of permeable borders at the edge of the nation, but because of the permeable borders at the edges of race and class.

The work of the Rainbow Coalition did not seek to discount the effect of white supremacy on people of color or reduce racism to capitalism. Instead, the Rainbow Coalition produced the radical notion that white supremacist capitalism harmed both whites and people of color and showed that multiracial resistance to such systems was possible, and in the interest of both groups. Such an approach, however, diverged greatly from the "beloved community" model of the earlier civil rights struggles, where integration in community organizations and the larger society was imagined by some as both the means and the ends of movement work. Rather, the Rainbow Coalition, and multiracial organizing work like it, charted a third path - one that denied both integration and segregation in its political means or ends. Instead, the BPP, Patriots, and Young Lords shared a strategic vision in the Rainbow Coalition as racially separate but allied 
organizations that worked to meet the material needs of their particular communities, while coalescing around the common goals of revolutionary justice, and an overthrow of white supremacist capitalism.

Bobby Lee offered additional insights into the power of the Rainbow Coalition, from the perspective of the US government:

It seems to me that a lot of the real intense government repression didn't happen until the Black Panthers started building real coalitions. Once the party departed from the "hate whitey" trip and got serious about building real politics, we were a threat plan and simple. The FBI were always watching us. But the Rainbow Coalition was their worst nightmare (Tracy 2006).

COINTELPRO, a counter-intelligence program of the FBI from 1956-1971, focused on the dismantling and destruction of radical and revolutionary opposition to the US government, and was at the forefront of the work against the Black Panthers in Chicago. A memorandum to the director of the FBI from the Chicago office in 1969 expressed specific concern about political alliances between the BPP and radical organizations of whites and other people of color:

The reference letter of May 1, 1969, was directed toward inhibiting an embryonic alliance formed locally recently between the Black Panther Party (BPP) and the Students for a Democratic Society (SDS)...A careful review and analysis of BPP activities locally...reflects that the tenuous working relationship between these two groups continues to exist and the activities and programs...continue to be valid.... In recent weeks also the local BPP group has affected a similar coalition with the Young Lords, a near north side Puerto Rican youth gang and the Young Patriots, the latter an off-shoot of Jobs or Income Now (JOIN), an SDS affiliated group of young whites. Chicago will follow this and related developments closely and as the opportunity presents itself will submit appropriate counterintelligence suggestions (Churchill 2002, 210).

From ongoing surveillance, to falsified communications, to police raids, to the eventual murder of Deputy Chairman of the Illinois State Chapter of the BPP, Fred Hampton, by Chicago police at the end 1969, COINTELPRO operations effectively ended what was revolutionary solidarity among poor people's organizations in the Rainbow Coalition. The organizers' sentiments and their radical models of coalition, however, would echo in future times and places.

Open Access This article is distributed under the terms of the Creative Commons Attribution 4.0 International License (http://creativecommons.org/licenses/by/4.0/), which permits unrestricted use, distribution, and reproduction in any medium, provided you give appropriate credit to the original author(s) and the source, provide a link to the Creative Commons license, and indicate if changes were made.

\section{References}

Alk, H. (Director). (2007a). The murder of Fred Hampton. Chicago; Facets Video. (Original work published 1971).

Alk, H. (Director). (2007b). American Revolution 2. Chicago, IL: Facet Videos. (Originally published 1969). 
Black Panther Party. (2002). Party platform and program: What we want, what we believe, October 1966. In P. S. Foner \& C. Carson (Eds.), The Black Panthers Speak. Cambridge, MA: Da Capo Press (Original work published 1970).

Churchill (2002) W. Churchill \& J. Vander Wall (Eds.), The COINTELPRO papers: documents from the FBI's secret wars against dissent. Cambridge, MA: South End Press.

Civil Rights and Labor History Consortium. (2019). Mapping the Black Panther Party in key cities. Retrieved September 17, 2019 from https://depts.washington.edu/moves/BPP_map-cities.shtml.

Cleaver, E. (1968). Revolution in the white mother country \& national liberation in the black colony. The North American Review, 253(4), 13-15.

Cleaver, K., \& Katsiaficas, G. N. (2001). Liberation, imagination and the Black Panther Party: a new look at the Panthers and their legacy. New York, NY: Routledge.

Draper, T. (1970). The rediscovery of black nationalism. New York, NY: Penguin.

Ebert, R. (2007). Roger Ebert's four-star reviews 1967-2007. Kansas City, MI: Andrews McMeel Publishing.

Epps, G. (1970). Huey Newton speaks at Boston College, presents theory of 'Intercommunalism,' The Harvard Crimson. https://www.thecrimson.com/article/1970/11/19/huey-newton-speaks-at-boston-college/. Accessed 19 Nov 1970.

Foner, P. S., \& Carson, C. (2014). The Black Panthers speak. Cambridge, MA: Da Capo Press.

Franklin, H. B. (1971). From the movement towardRevolution. New York, NY: Van Nostrand Reinhold.

Frederickson, G. M. (1987). The black image in the white mind: the debate on Afro-American character and destiny, 1817-1914. Wesleyan, MA: Wesleyan University Press.

Hampton, F. (1969). Power anywhere where there's people! Freedom Archives. https://www. historyisaweapon.com/defcon1/fhamptonspeech.html.

Heath, G. L. (1976). Off the pigs!: The history and literature of the Black Panther Party. Lanham, MD: Rowman \& Littlefield.

Howard, E. (2006). Invitation to fortieth year reunion and celebration of the Black Panther Party, October 1315, 2006. Retrieved from https://www.scribd.com/document/181029451/Solidarity.

Jones, C. E. (1998). The Black Panther Party (Reconsidered). Baltimore, MD: Black Classic Press.

Joseph, P. E. (2006). Waiting 'tiil the midnight hour: a narrative history of black power in America. New York, NY: Owl Books.

Joyce, B. (1970). Young patriots: liberation news service (December 30, 1969). In M. Goodman (Ed.), The Movement Toward a New America. New York, NY: Knopf.

Kaufman, M.T. (1969). Black Panthers join coalition with Puerto Rican and Appalachian groups. The New York Times, pp. 83. https://www.nytimes.com/1969/11/09/archives/black-panthers-join-coalition-withpuerto-rican-and-appalachian.html.

King Jr., M. L., King, C. S., \& Harding, V. (1986). Where do we go from here: chaos or community? New York, NY: Beacon Press (Originally published 1967).

Marx, K. (1913). The eighteenth brumaire of Louis Bonaparte. Chicago, IL: Charles H. Kerr \& Company (Original work published 1852) The Movement. (November 1967). We've got to reach our own people: a plan for white resistance, pp. 8-15.

Ogbar, J. O. G. (2006). Brown power to brown people: radical ethnic nationalism, the Black Panthers, and Latino radicalism, 1967-1973. In J. Lazerow \& Y. Williams (Eds.), In search of the Black Panther Party: new perspectives on a revolutionary movement (p. 2006). Durham, NC: Duke University Press.

Plato. (1908). The republic. Oxford: Clarendon Press (Original work published in 380 BCE).

Rushdy, A. H. A. (1999). Neo-slave narratives: studies in the social logic of a literary form (p. 1999). New York, NY: Oxford University Press.

Schnell, F., Terkildsen, N., \& Callaghan, K. (2000). Symbolism and social movements: how U.S. political debates are shaped and citizens' attitudes influenced by symbolic sommuniqués. In C. Landtsheer \& O. Feldman (Eds.), Beyond public speech and symbols: explorations of rhetoric of politicians and the media. Westport, CT: Greenwood Publishing Group.

Sonnie, A. \& Tracey, J. (2008). Uptown's JOIN Community Union 1964-1966. In The inheritance of politics: a local reader on the legacy of 1968 in Chicago. Chicago, IL: AREA. https://readwritelibrary. org/catalog/area-chicago-7-inheritance-politics-2008.

Southern Student Organizing Committee. (1964). We'll take our stand. In W. Constance (Ed.), Curry papers. Atlanta, GA: Manuscripts Archives and Rare Book Library, Robert W. Woodruff Library, Emory University.

Carmichael, S., \& Hamilton, C. V. (1967)Black power: the politics of liberation in America. New York, NMY: Random House. In-text citation appears in first paragraph under The Politics of Liberation header and Hamilton's work, Black Power: The Politics of Liberation in America. 
The Movement. (1968). Huey Newton talks to the movement about the Black Panther Party, cultural nationalism, SNCC, liberals and white revolutionaries, pp. 8-11. Chicago: Students for a Democratic Society.

The New York Times. (1966). Excerpts from paper on which the 'Black Power' philosophy is based," pp. 10. https://www.nytimes.com/1966/08/05/archives/excerpts-from-paper-on-which-the-black-powerphilosophy-is-based.html?searchResultPosition=55.

Tracy, J. (2006). The (original) Rainbow Coalition. Chicago, IL: AREA.

Publisher's Note Springer Nature remains neutral with regard to jurisdictional claims in published maps and institutional affiliations. 